\title{
TEMPORARY INTERRUPTION OF THE MORPHOGENESIS OF DECIDUOMATA IN THE MOUSE UTERUS BY ACTINOMYCIN D
}

\author{
C. A. FINN AND L. MARTIN \\ Department of Physiology, Royal Veterinary College, London, $\mathcal{N} . W .1$, and \\ Department of Hormone Physiology, Imperial Cancer Research Fund, \\ Lincolns Inn Fields, London, W.C.I
}

(Received 20th October 1971, accepted 6th December 1971)

\begin{abstract}
Summary. A single injection of $15 \mu \mathrm{g}$ actinomycin D on Day 5 after mating interrupted pregnancy in five/five mice. To obtain information about the mode of action of the drug, its effect on the progress of the artificial decidual cell reaction was studied.

Ovariectomized mice were prepared for decidualization with exogenous hormones and decidualization induced by the intrauterine injection of arachis oil. Intraperitoneal injection of actinomycin D $7 \frac{1}{2}$ or $1 \frac{1}{2} \mathrm{hr}$ before the decidual stimulus did not prevent the early stages of the decidual reaction but delayed by 24 to $30 \mathrm{hr}$ the onset of decidual transformation of the stromal cells. It appears that the drug blocks the chain of reactions leading to decidual morphogenesis after the initiation of the reaction but that once the effect of the drug wears off, development of the decidua resumes provided the hormone conditions are adequate.
\end{abstract}

\section{INTRODUCTION}

Transformation of the fibroblasts of the endometrium into decidual cells with the formation of the implantation chamber is a rare example of morphogenesis in the adult mammal (Krehbiel, 1937; Finn, 1971). The preparation of the endometrium for the reaction is under strict endocrine control, which can however be mimicked by exogenous hormones in ovariectomized animals (Psychoyos, 1967a; DeFeo, 1967; Marcus \& Shelesnyak, 1970). In rodents, a stimulus is required to initiate the reaction in the sensitized uterus. The nature of the stimulus is unknown but although it is normally given by the blastocyst, it can be replaced by certain artificial stimuli, such as intrauterine oil (Finn \& Keen, 1963), air (Orsini, 1963) or trauma (Loeb, 1908).

In view of the importance of RNA in the decoding and transfer of information from the nucleus and its consequent rôle in the control of morphogenic processes, it is not surprising that it has been implicated in the biology of the uterus during the preparation for deciduogenesis and during the decidual cell reaction (Shelesnyak \& Tic, 1963; Wada, Segal \& Schuchner, 1965; Psychoyos, 
1967b). Actinomycin D has been shown to prevent the traumatic decidual cell reaction in pseudopregnant rats (Glasser, 1965; Burin \& Sartor, 1965) and it is assumed that its effect is due to inhibition of the synthesis of DNA-dependent RNA.

In the pseudopregnant animal, the uterus is dependent on a continued supply of progesterone from the corpora lutea, which are themselves dependent on gonadotrophic hormones from the hypothalamic/pituitary system. It is quite possible that the administration of actinomycin $D$ would upset the supply of ovarian hormones either at the level of the corpora lutea or the hypothalamic/ pituitary system. The effect on decidualization might, therefore, be complicated by hormone deficiency.

To avoid this, the effect of actinomycin $\mathrm{D}$ on the progress of decidualization has been evaluated in ovariectomized mice treated with exogenous hormones on a schedule which has previously been shown to allow decidualization in response to the intrauterine injection of oil (Finn \& Martin, 1969).

\section{MATERIALS AND METHODS}

Random-bred albino mice were ovariectomized through a dorsal incision under Avertin anaesthesia. Hormones were given by subcutaneous injection in $0.05 \mathrm{ml}$ arachis oil. To obtain a decidual cell reaction, the following schedule of hormones was given: Days 1,2 and 3, 0.1 $\mu$ g oestradiol-17 $\beta$; Days 4, 5 and 6, no hormones; Days 7 to $9,0.01 \mu \mathrm{g}$ oestradiol- $17 \beta$ plus $500 \mu \mathrm{g}$ progesterone; Day 10 to autopsy, $500 \mu \mathrm{g}$ progesterone. The decidual stimulus was the injection of $0.01 \mathrm{ml}$ arachis oil into the left horn of the uterus through the uterotubal junction. This was carried out on Day 9,6 hr after the hormone injections.

Actinomycin D was injected intraperitoneally in $0.1 \mathrm{ml}$ water at the times indicated in the text. The dose used was $15 \mu \mathrm{g}$. This dose was based on earlier experiments on mice (Barros \& Austin, 1968) and confirmed in preliminary experiments to be effective without being too toxic.

In order to follow the course of the decidual reaction, the animals were killed at various times after the decidual stimulus and the two horns of the uterus weighed separately. The difference in weight between the injected and noninjected horn is taken as a measure of the weight of decidual tissue formed. Fifteen minutes before autopsy, $0.25 \mathrm{ml}$ of a $1 \%$ solution of Pontamine sky blue was injected into a tail vein. One of the earliest recognizable signs of a decidual reaction is increased permeability of the blood vessels of the endometrium supplying the reacting area and consequent staining with Pontamine sky blue 6BX (Psychoyos, 1961). Blue areas of the uteri were fixed either in Bouin's fluid for histology, or in $80 \%$ alcohol for the histochemical detection of alkaline phosphatase in the stroma of the endometrium which confirms the onset of decidualization (Finn \& Hinchliffe, 1964).

\section{RESULTS}

Experiment 1. Effect of actinomycin $D$ on pregnancy

This was a preliminary experiment to confirm that the dose of drug used was 
sufficient to upset the course of pregnancy. Ten females were placed with males and the day of finding the vaginal plug designated Day 1 of pregnancy. On Day 5, five of the females were injected with actinomycin D $(15 \mu \mathrm{g})$, and five with a similar volume of water. All the animals in the latter group had normal litters, whereas none of the actinomycin-treated animals had a litter.

\section{Experiment 2. Effect of actinomycin $D$ on the progress of decidualization}

Ovariectomized mice were prepared for decidualization and given a single injection of actinomycin D $1 \frac{1}{2}$ or $7 \frac{1}{2} \mathrm{hr}$ before the application of the decidual stimulus. Thus, the former group received the drug after the hormone injections on Day 9 whilst the latter received it $1 \frac{1}{2} \mathrm{hr}$ before receiving the hormone. In the first trial, the mice were killed $24 \mathrm{hr}$ after the application of the decidual stimulus. The results are shown in Table 1.

The administration of actinomycin $\mathrm{D}$ had no effect on the onset of the Pontamine sky blue reaction but a very pronounced effect on the weight increase of the injected horns. That this was due to inhibition of the decidual cell reaction

\section{TABLE 1}

THE EFFECT OF AGTINOMYGIN D ON THE INITIAL DEGIDUAL REAGTION IN THE MOUSE UTERUS

\begin{tabular}{|c|c|c|c|}
\hline Treatment & No. of mice & $\begin{array}{c}\text { No, of mice } \\
\text { showing P.S.B. }\end{array}$ & Decidual weight \\
\hline 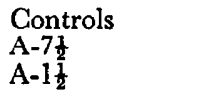 & $\begin{array}{l}5 \\
5 \\
5\end{array}$ & $\begin{array}{l}5 \\
5 \\
5\end{array}$ & $\begin{array}{r}56.0 \pm 9.4 \\
5.2 \pm 1.9 \\
10.0 \pm 2.7\end{array}$ \\
\hline
\end{tabular}

A- $7 \frac{1}{2}\left(-1 \frac{1}{2}\right)=15 \mu \mathrm{g}$ actinomycin D administered $7 \frac{1}{2}\left(1 \frac{1}{2}\right) \mathrm{hr}$ before the decidual stimulus (intrauterine oil). Decidual weight = weight of uterine horn injected with oil less weight of uninjected horn, expressed as mean \pm S.E. (mg). P.S.B. = positive Pontamine sky blue reaction. All animals killed $24 \mathrm{hr}$ after the injection of the oil decidual stimulus.

was clearly shown by histological and histochemical examination of the uteri. All the uteri of the control animals had a normal early decidual reaction, with a crescent of stromal tissue around the antimesometrial end of the lumen which reacted positively for alkaline phosphatase. In the actinomycin-treated animals, there was little or no histological evidence of decidualization and no alkaline phosphatase reaction. There was, however, some thinning of the epithelium in the injected horns of these animals and the stroma was oedematous around the antimesometrial end of the lumen. The latter, in conjunction with the positive Pontamine sky blue reaction, indicates that the decidual reaction had been initiated, but had been prevented from progressing beyond the oedema stage.

In the subsequent experiments, the actinomycin $\mathrm{D}$ was given and the uteri were treated as before, but the animals were killed 24,48 or $72 \mathrm{hr}$ after the application of the decidual stimulus. The results are shown in Table 2. The experiments were carried out on two separate occasions as indicated.

At $24 \mathrm{hr}$, the animals showed the same response as in the previous experiment. At $48 \mathrm{hr}$, all of the control animals showed a large increase in the weight 
of the injected horns and histological examination revealed a typical decidual reaction and positive response for alkaline phosphatase throughout most of the stroma. By contrast, none of the treated animals showed a significant increase in the weight of the injected horn, although they all had a positive Pontamine sky blue reaction. Histological examination demonstrated the absence of decidualization in most uteri, although in a few a very early reaction in the stroma was apparent. Similarly, the reaction for alkaline phosphatase was absent in the stroma of most of the uteri although a few had a small positive crescent around the antimesometrial end of the lumen, indicating an early decidual response.

At $72 \mathrm{hr}$, all the groups, both treated and control, showed a marked increase in decidual weight and normal-looking deciduomata were macroscopically visible in the injected horns. Sections from the uteri of the control animals

TABLE 2

THE EFFECT OF AGTINOMYGIN D ON DEGIDUAL GELL PRODUGTION IN MICE OVER THE FIRST 72 HR

\begin{tabular}{|c|c|c|c|c|}
\hline Treatment & Autopsy & No. of mice & $\begin{array}{l}\text { No. of mice } \\
\text { showing P.S.B. }\end{array}$ & Decidual weigh \\
\hline 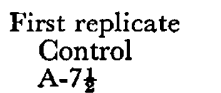 & $24 \mathrm{hr}$ & $\begin{array}{l}4 \\
5\end{array}$ & $\begin{array}{l}4 \\
5\end{array}$ & $\begin{array}{l}39 \cdot 5 \pm 18 \cdot 6 \\
12 \cdot 2 \pm 3 \cdot 9\end{array}$ \\
\hline 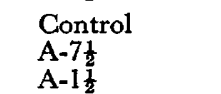 & $48 \mathrm{hr}$ & $\begin{array}{l}4 \\
5 \\
4\end{array}$ & $\begin{array}{l}4 \\
5 \\
4\end{array}$ & $\begin{array}{r}120 \cdot 7 \pm 20.2 \\
11 \cdot 0 \pm 3.7 \\
24 \cdot 2 \pm 3.9\end{array}$ \\
\hline $\begin{array}{l}\text { Control } \\
\text { A-7 } \frac{1}{2} \\
\text { A-1 } \frac{1}{2}\end{array}$ & $72 \mathrm{hr}$ & $\begin{array}{l}4 \\
5 \\
4\end{array}$ & $\begin{array}{l}4 \\
5 \\
4\end{array}$ & $\begin{array}{r}119 \cdot 7 \pm 47 \cdot 3 \\
54 \cdot 4 \pm 18 \cdot 1 \\
69 \cdot 0 \pm 8 \cdot 0\end{array}$ \\
\hline $\begin{array}{l}\text { Second replicate } \\
\text { Control } \\
\text { A-1 } \frac{1}{2}\end{array}$ & $24 \mathrm{hr}$ & $\begin{array}{l}5 \\
4\end{array}$ & $\begin{array}{l}5 \\
3\end{array}$ & $\begin{array}{r}27 \cdot 2 \pm 2 \cdot 1 \\
9 \cdot 0 \pm 3 \cdot 9\end{array}$ \\
\hline $\begin{array}{l}\text { Control } \\
\text { A- } 1 \frac{1}{2}\end{array}$ & $48 \mathrm{hr}$ & $\begin{array}{l}5 \\
5\end{array}$ & $\begin{array}{l}5 \\
5\end{array}$ & $\begin{array}{r}69 \cdot 2 \pm 9 \cdot 8 \\
7 \cdot 2 \pm 0 \cdot 8\end{array}$ \\
\hline $\begin{array}{l}\text { Control } \\
\mathrm{A}-1 \frac{1}{2}\end{array}$ & $72 \mathrm{hr}$ & $\begin{array}{l}5 \\
5\end{array}$ & $\begin{array}{l}5 \\
5\end{array}$ & $\begin{array}{l}95 \cdot 0 \pm 11 \cdot 8 \\
33 \cdot 2 \pm 5 \cdot 8\end{array}$ \\
\hline
\end{tabular}

Abbreviations as for Table 1 .

showed that they contained normal 72-hr decidual reactions. Sections from the swellings from the uteri of the treated animals also revealed normal decidual tissue, but at a very much earlier stage of development than the controls. They were a little less developed than the 48-hr controls but more advanced than those killed at $24 \mathrm{hr}$.

\section{DISCUSSION}

These results demonstrate that actinomycin $\mathrm{D}$ does not prevent the earliest uterine changes in response to a decidual stimulus. The Pontamine sky blue reaction, an indication of increased vascular permeability (Psychoyos, 1961), is the first observable sign of an implantation reaction in mice (Finn \& McLaren, 1967). It occurred regularly in the actinomycin D-treated mice, coincidental 
with its appearance in control uteri. The second easily observable change is stromal oedema. This response, although much more difficult to quantify, appeared at the usual time in most of the treated animals. Decidual transformation of the stromal cells on the other hand, which in the controls was well advanced by $48 \mathrm{hr}$, was absent or very reduced at this time in the uteri of the treated animals. Apart from histological evidence, this was reflected in the decidual weight and the diminution of the alkaline phosphatase reaction in the stroma. In many cases, the treated uteri showed increased oedema, but this was inconsistent and difficult to quantify.

At $72 \mathrm{hr}$, all the actinomycin D-treated animals had a decidual reaction. The injected horns showed a definite increase in weight, although considerably less than the controls at this time. Histologically, the decidual tissue of the treated animals was normal but at that stage of development which is normally reached in 30 to $40 \mathrm{hr}$. Alkaline phosphatase was present in the stroma.

Apparently, actinomycin D does not interfere with the initiation of decidual morphogenesis, but delays one of the steps in the sequence of reactions between stromal oedema and cellular transformation. The interruption, however, is temporary and provided the correct hormone conditions are maintained, decidual morphogenesis continues after the effects of the drug have disappeared.

The finding that decidual morphogenesis can be held in abeyance is surprising. It should be stressed that it is not similar to the condition of delayed implantation where the uterus is held in a state of unresponsiveness to the decidual stimulus (the blastocyst) due to a withholding of the correct hormone conditions. With actinomycin $\mathrm{D}$, the uterus is sensitive and the stimulus is effected but delay occurs after the initiation of the morphogenic processes leading to decidualization.

At present, it is too early to postulate on the mechanisms involved in causing this interruption, but it is hoped that the response to actinomycin D may assist in determining the control mechanisms involved in the uterine reactions during implantation.

\section{AGKNOWLEDGMENTS}

Our thanks are due to Miss C. Seaman and Mrs G. Parke for technical assistance. This work was supported in part by a grant to one of us from the Medical Research Council.

\section{REFERENGES}

BARros, C. \& Austin, C. R. (1968) Inhibition of ovulation by systemically administered actinomycin $\mathrm{D}$ in the hamster. Endocrinology, 83, 177.

Burin, P. \& Sartor, P. (1965) Inhibition de la réaction déciduale par l'actinomycine D. C. r. Séanc. Soc. Biol. 159, 141.

DeFeo, V. J. (1967) Decidualization. In: Cellular Biology of the Uterus, p. 191. Ed. R. M. Wynn. Appleton-Century-Crofts, New York.

Frns, C. A. (1971) The biology of decidual cells. In: Advances in Reproductive Physiology, Vol. 5, 1. Ed. M. W. H. Bishop. Logos Press, London.

Fins, C. A. \& Hinchumfe, J. R. (1964) The reaction of the mouse uterus during implantation and deciduoma formation as demonstrated by changes in the distribution of alkaline phosphatase. 7. Reprod. Fert. 8, 331. 
Finn, C. A. \& KeEN, P. M. (1963) The induction of deciduomata in the rat. F. Embryol. exp. Morph. 11, 673.

Finn, C. A. \& McLaren, A. (1967) A study of the early stages of implantation in mice. F. Reprod. Fert. $13,259$.

Finn, C. A. \& Martin, L. (1969) Hormone secretion during early pregnancy in the mouse. F. Endocr. $45,57$.

Grasser, S. R. (1965) Biochemical studies on a cellular receptor mechanism for uterine sensitivity. Excerpta Med. Int. Congr. Series, 99, 335.

KREHBIEL, R. H. (1937) Cytological studies of the decidual reaction in the rat during early pregnancy and in the production of deciduomata. Physiol. Zoöl. 10, 212.

LoEB, L. (1908) The experimental production of the maternal placenta and the formation of the corpus luteum. F. Am. med. Ass. 50, 1897.

Marcus, G. J. \& Shelesnyak, M. C. (1970). Steroids in nidation. In: Advances in Steroid Biochemistry. Ed. M. H. Briggs. Academic Press, London and New York.

Orsins, M. W. (1963) Induction of deciduomata in hamsters and rats by injected air. F. Endocr. 28, 119.

Psychoyos, A. (1961) Perméabilité capillaire et decidualization utérine. C. r. hebd. Séanc. Acad. Sci., Paris, 252, 1515.

Psychoyos, A. (1967a) The hormonal interplay controlling egg-implantation in the rat. In: Advances in Reproductive Physiology, Vol. 2, p. 257. Ed. Anne McLaren. Logos Press, London.

Psychoyos, A. (1967b) Mécanismes de la nidation. Archs Anat. microsc. Morph. exp. 56, 616.

Shelesnyak, M. G. \& Tic, L. (1963) Studies on the mechanisms of decidualization. IV. Synthetic processes in the decidualizing uterus. Acta endocr., Copenh. 42, 465.

WAdA, K., Segal, S. J. \& Schuchner, E. (1965) Role of RNA in initiation of nidation of blastocysts. 23rd Int. Congr. of Physiol. Sci., Tokyo, p. 278. 